\title{
First record of the new alien sea jelly species Marivagia stellata Galil and Gershwin, 2010 off the Syrian coast
}

\author{
S. Mamish ${ }^{1 *}$, H. Durgham² and M. S. AL-Masri ${ }^{1}$
}

\begin{abstract}
Marivagia stellata Galil and Gershwin, 2010 (Scyphozoa: Rhizostomeae: Cepheidae), was recorded for the first time off the Syrian coast on the 6th of July 2015. Several specimens of the alien sea jelly species M. stellata were observed very close to the port of Lattakia, and a single specimen was caught, at a depth of $7 \mathrm{~m}$ by a professional scuba diver during a regular sea jelly monitoring program.

The occurrence of non-indigenous sea jelly species in the Syrian coastal waters may be related to the introduction of Indo-Pacific and Red Sea origin species into the Mediterranean Sea through the Suez Canal. The growing list of alien sea jelly indicates that considerable changes are occurring in the eastern Mediterranean marine environment.
\end{abstract}

Keywords: Alien sea jelly, Jellyfish, Marivagia stellata, Mediterranean Sea, Levantine, Syrian coast

\section{Introduction}

Over recent decades, man's expanding influence on the oceans has caused significant changes on marine biodiversity, including sea jelly. There is a reason to think that in some regions, high abundances and massive new blooms of numerous non-indigenous sea jelly species are occurring in response to the cumulative effects of global change (Mills 2001, Purcell et al. 2007). Many reports of human problems with sea jelly have increased and captured public attention. Such problems come mainly from sea jelly stinging swimmers and interfering with fishing, aquaculture and power plant operations (Malej 2001; Pagès 2001; Benovic and Lucic 2001; Lynam 2006; Boero et al. 2008; Licandro et al. 2010; Sakınan 2011; Turan and Ozturk 2011; Mamish et al. 2012).

Negative impacts of the sea jelly outbreaks on human coastal activities have persuaded Tishreen University, High Institute of Marine Research and the Atomic Energy Commission of Syria, to initiate a sea jellymonitoring program for surveying the Syrian coast (Northern Levantine coast). The list of the new alien sea jelly species recorded recently in the Syrian costal water

\footnotetext{
* Correspondence: prscientific@aec.org.sy

'Department of Protection and Safety, Atomic Energy Commission of Syria, Damascus, Syria

Full list of author information is available at the end of the article
}

(eastern Mediterranean Sea) is increasing. Phyllorhiza punctata von Lendenfeld, 1884, Aequorea globosa Eschscholtz, 1829, Cassiopea andromeda Forsskål, 1775, and Rhopilema nomadica Galil, 1990 have been recently recorded and they are mostly of Indo-Pacific and Red Sea origin introduced through the Suez Canal (Ikhtiyar et al. 2002; Durgham 2011; Mamish et al. 2012; Siokou et al. 2013; Mamish et al. 2015).

Here, we describe the first record of another alien sea jelly Marivagia setllata Galil and Gershwin 2010.

\section{Material and methods}

Approximately 60 specimens of this new sea jelly species were found during a regular sea jelly monitoring program by a professional scuba diver for the first time, on the 6th of July 2015, from a site very close to the port of Lattakia (lat. $32^{\circ} 31^{\prime \prime} 22.7^{\prime} \mathrm{N}$, long. $35^{\circ} 44^{\prime \prime} 35.3^{\prime} \mathrm{E}$ ) on the Syrian coast. A single specimen was caught at depth of $7 \mathrm{~m}$ using a hand-net. The temperature and salinity at the sampling time were $25^{\circ} \mathrm{C}$ and $39 \%$ respectively. The specimen was taken to the laboratory and immediately examined while still alive, photographed, fixed in $4 \%$ formaldehyde and stored in the zooplankton laboratory, High Institute of Marine Research (Fig. 1).

The umbrella diameter and the wet weight of the collected specimen were $14.5 \mathrm{~cm}$ and $150 \mathrm{~g}$, respectively. 


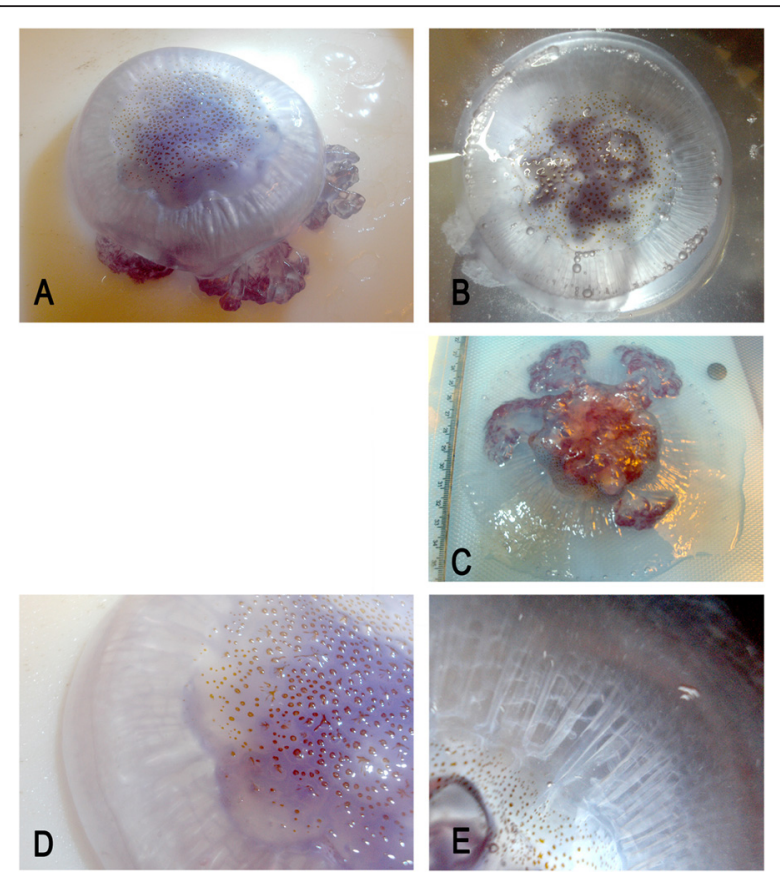

Fig. 1 Marivagia stellata Galil and Gershwin, 2010 off the Syrian coast. $\mathbf{a}$ and $\mathbf{b}$ : Aboral view. c: Oral view. d: Close up of exumbrellar pigmentation pattern. e: Lappets and radial canals

The new species was identified as Marivagia stellata Galil and Gershwin, 2010 (Scyphozoa: Rhizostomeae: Cepheidae) by its unique combination of the remarkable morphological based on relevant characters as defined by Galil et al. 2010 .

Marivagia stellata is a translucent bluish-white sea jelly, the exumbrella surface lacks central dome, warts, or knobs, ornamented with conspicuous pattern of reddish stars, dots and streaks clustered in center third of exumbrella (Fig. 1a, b, d and e). Subumbrella lacks filaments on oral disk and between mouths (Fig. 1c).

\section{Results and discussion}

The earliest record of Marivagia stellata Galil and Gershwin, 2010 species was initially described in 2010 from the southeastern Levantine coast of the Mediterranean Sea (Galil et al. 2010; Zaatari 2010. Later, in 2013, this species was reported from Kerala, India in the south-east of the Arabian Sea (Galil et al. 2013), and after that the species has been found off the mouth of the River Indus, Pakistan in 2014 for the first time (Gul et al. 2014). Even though the species has been discovered in the Mediterranean water before its discovery in the Indian Ocean, Galil et al. (2010) argued that M. stellata is a non-indigenous species. It is highly unlikely that a large native littoral species, markedly different from all known scyphozoans in the Mediterranean, would remain unknown until the 21 century. As the Southeastern Levant has been inundated by alien biota, it is likely $M$. stellata is an alien as well (Galil et al. 2010; Galil et al. 2013). It has been suggested that the origin of M. stellata species is from the Indian Ocean. It probably entered the Mediterranean Sea through the Suez Canal; in accordance with invasions of non-indigenous species continue documented recently in the eastern Mediterranean Sea (Zenetos et al. 2010; Galil et al. 2013; Galil et al. 2015). Therefore, the occurrence of this alien sea jelly species in the Syrian coastal waters may be due to the introduction of the Indo-Pacific origin species into the Mediterranean Sea through the Suez Canal. $M$. stellata is a true sea jelly and has a complex bipartite life-history. It has a typically cryptic sessile, asexually reproducing polypoid stage, which can asexually produce large numbers of planktonic young medusa (ephyra), followed by a pelagic and sexually reproducing medusa stage (Graham et al. 2007). Therefore, ephyra may have been carried with the Levantine coastal currents, as the case of the sea jelly species Aequorea globosa (Mamish et al. 2012), or as polyps in ship fouling or ballast water of ships, as the case of the sea jelly species Phyllorhiza punctata (Abed-Navandi and Kikinger 2007, Boero et al. 2009, Gueroun et al. 2014). The sudden appearance of 60 sexually mature specimens of the new alien sea jelly species together at the same time may be attributed to the fact that local population that has been already established close to the major port of Lattakia. This suggests transportation of species on ship hulls of the sessile polyp originates in the Indian Ocean, where the origin of all Cephidae genus were reported (Kramp 1961). However, such a complex bipartite life history severely limits our ability to understand origins and fates of this sea jelly species invasion (Graham et al. 2007).

This alien sea jelly species is rare so far in the Mediterranean Sea. There is little information about its effects on humans, apparently, it is not a sea jelly stings humans and it presumably has nematocysts. Further investigations on the isolation and characterization of venom from nematocysts of sea jelly $M$. stellata and its effects are needed.

New invasions of non-indigenous sea jelly species continue to be documented in the Syrian coastal waters in recent years, where M. stellata is the fourth scyphozoan species introduced to the Syrian coastal waters through the Suez Canal from the Indian Ocean. In addition, the growing list of alien sea jelly species indicates that considerable changes are occurring in the eastern Mediterranean marine environment. This makes the sea jelly monitoring program of critical importance both as an indicator of climate change, and for the ecological effects that such alien species may have on local species, communities and ecosystems (Mills 2001; Purcell et al. 2007; Zenetos et al. 2010; Galil et al. 2015). 


\section{Conclusion}

Herein, we recorded a new alien sea jelly species, the Marivagia stellata Galil and Gershwin, 2010 (Scyphozoa: Rhizostomeae: Cepheidae) off the Syrian coast for the first time. The occurrence of this alien sea jelly species in the Syrian coastal waters may be related to the introduction of the Indo-Pacific origin species into the Mediterranean Sea through the Suez Canal. The sudden appearance of 60 sexually mature specimens of new alien sea jelly species together at the same time may be attributed to a local population has been already established close to the major port of Lattakia. This suggests transportation of species on ship hulls of the sessile polyp originates in the Indian Ocean introduced by vessels traversing the Suez Canal.

\section{Acknowledgements}

The authors would like to thank Prof. Ibrahim Othman (G.D. of AECS) for his encouragement and support. Much appreciation is due to Prof. Abdulkareem Mohammad (Dean of The High Institute of Marine Research) for his cooperation.

\section{Author's contributions \\ All three of the authors are working in the Syrian sea jelly monitoring program team. SM: carried out the photographing and classification of the new species, and drafted the manuscript. HD: participated in the sampling and classification of the new species. M. S. Al-M: participated in design and coordination and helped to draft the manuscript. All authors read and approved the final manuscript.}

\section{Competing interests}

The authors declare that they have no competing interests.

\section{Author details}

${ }^{1}$ Department of Protection and Safety, Atomic Energy Commission of Syria, Damascus, Syria. ${ }^{2}$ Department of Marine Biology, Tishreen University, High Institute of Marine Research, Lattakia, Syria.

Received: 13 January 2016 Accepted: 26 April 2016

Published online: 10 July 2016

\section{References}

Abed-Navandi D, Kikinger R. First record of the tropical scyphomedusa Phyllorhiza punctata von Lendenfeld, 1884 (Cnidaria: Rhizostomeae) in the central Mediterranean Sea. Aquat Invasions. 2007;2:391-4.

Benovic A, Lucic D. Jellyfish outbreaks: natural cycle or stress response effect. In: CIESM Gelatinous zooplankton outbreaks: theory and practice". 14th ed. Monaco: CIESM Workshop Series; 2001. p. 59-62.

Boero F, Bouillon J, Gravili C, Miglietta MP, Parsone T, Piraino S. Gelatinous plankton: irregularities rule the world (sometimes). Mar Ecol Prog Ser. 2008:356:299-310.

Boero F, Putti M, Trainito E, Prontera E, Piraino S, Shiganova TA. First records of Mnemiopsis leidyi (Ctenophora) from the Ligurian, Thyrrhenian and Ionian Seas (Western Mediterranean) and first record of Phyllorhiza punctata (Cnidaria) from the Western Mediterranean. Aquat Invasions. 2009:4:675-80.

Durgham H. First Records of Phyllorhiza punctata von Lendenfeld, 1884 (Cnidaria: Rhizostomeae) from the Mediterranean Coast of Syria. Int J Oceans Oceanography. 2011;5(2):153-5.

Galil B, Boero F, Campbell M, Carlton J, Cook E, Fraschetti S, et al. Double trouble: the expansion of the Suez Canal and marine bioinvasions in the Mediterranean Sea. Biol Invasions. 2015;17:973-6.

Galil BS, Gershwin LA, Douek J, Rinkevich B. Marivagia stellata gen. et sp. nov. (Scyphozoa: Rhizostomeae: Cepheidae), another alien jellyfish from the Mediterranean coast of Israel. Aquat Invasions. 2010;5:331-40.

Galil BS, Kumar BA, Riyas AJ. Marivagia stellata Galil and Gershwin, 2010 (Scyphozoa: Rhizostomeae: Cepheidae), found off the coast of Kerala, India. Bio Invasions Records. 2013;2(4):317-8.
Graham W.M. and Bayha K.M. Biological Invasions by Marine Jellyfish, Ecological Studies, Vol. 193, Springer-Verlag, 2007. pp 239-255

Gueroun, S. K. M., Kéfi-Daly Yahia O., Deidun A., Fuentes V., Piraino S. and Daly Yahia M. N. First record and potential trophic impact of Phyllorhiza punctata (Cnidaria: Scyphozoa) along the north Tunisian coast (South Western Mediterranean Sea). Ital J Zool. 2014;1:1-6.

Gul S, Moazzama M, Galila B. Occurrence of Marivagia stellata (Scyphozoa: Rhizostomeae: (epheidae) along the coast of Pakistan, northern Arabian Sea. Mar Biodivers Rec. 2014;7:112-3.

Ikhtiyar S, Durgham H, Baker M. Contribution à l'étude du scyphoméduse Rhopelima nomadica dans les eaux côtières Syriennes and biochemical composition. J Union Arab Biol Cairo A Zool. 2002;18:227-44.

Kramp PL. Synopsis of the Medusae of the World. J Mar Biol Assoc U K. 1961;40:469p.

Licandro P.., Conway D.V.P., Daly Yahia MN., Fernandez de Puelles ML., Gasparini S., Hecq JH., Tranter P., Kirby R.R. A blooming jellyfish in the northeast Atlantic and Mediterranean. Biol Lett. 2010;6:688-691.

Lynam CP. Ecological and acoustic investigations of jellyfish (Scyphozoa and Hydrozoa)". University of St Andrews: Christopher Philip. PhD Thesis; 2006.

Malej A. Are irregular plankton phenomena getting more frequent in the northern Adriatic Sea? In: CIESM Gelatinous zooplankton outbreaks: theory and practice. CIESM Workshop Series, Monaco. 2001;14:67-8.

Mamish S, Al-Masri MS, Durgham H. Radioactivity in three species of eastern Mediterranean jellyfish. J Environ Radioact. 2015;149:1-7.

Mamish S, Durgham H, Al-Masri MS. First record of Aequorea globosa Eschscholtz, 1829 (Cnidaria: Hydrozoa) in the coast of Syria. Mediterr Mar Sci. 2012;13(2):259-61.

Mills CE. Jellyfish blooms: Are populations increasing globally in response to changing ocean conditions? Hydrobiologia. 2001;451:55-68.

Pagès F. Past and present anthropogenic factors promoting the invasion, colonization and dominance by jellyfish of a Spanish coastal lagoon. In: CIESM Gelatinous zooplankton outbreaks: theory and practice. 14th ed. Monaco: CIESM Workshop Series; 2001. p. 69-74.

Purcell JE, Uye SI, Lo T. Anthropogenic causes of jellyfish blooms and their direct consequences for humans: a review. Mar Ecol Prog Ser. 2007;350:153-74.

Sakınan S. Recent occurrence of indopacific jellyfish Rhopilema nomadica in North-Eastern Levantine Sea. Bodrum, Turkey: First national workshop on jellyfish and other gelatinous species in Turkish marine waters; 2011. p. 58-65.

Siokou I, Ate AS, Ayas D, Ben Souissi J, Chatterjee T, Dimiza M, et al. Mediterranean marine science, new Mediterranean marine biodiversity records. Medit Mar Sci. 2013;14(1):238-49.

Turan C, Ozturk B. First national workshop on jellyfish and other gelatinous species in Turkish marine waters. Istanbul, Turkey: Published by Turkish Marine Research Foundation; 2011. p. 35.

Zaatari M. "Odd marine changes strike coast of Sidon". Daily Star. Retrieved October 17, 2010.

Zenetos A., Gofas S., Verlaque M., Çinar M.E., Garcia Raso J.E. Alien species in the Mediterranean Sea by 2010. A contribution to the application of European Union's Marine Strategy Framework Directive (MSFD). Part I. Spatial distribution. Mediterranean Marine Science. 2010. 11 (2), pp. 381-493

Submit your next manuscript to BioMed Central and we will help you at every step:

- We accept pre-submission inquiries

- Our selector tool helps you to find the most relevant journal

- We provide round the clock customer support

- Convenient online submission

- Thorough peer review

- Inclusion in PubMed and all major indexing services

- Maximum visibility for your research

Submit your manuscript at www.biomedcentral.com/submit 